\title{
Participatory Land Governance in Mozambique: Brief Review of the Legal Framework and the Implementation Challenge
}

\author{
Alda Salomão
}

I Tindzila Land Governance Resources Centre, Maputo, Mozambique

\begin{abstract}
A commitment to democracy and popular participation in the national development has been a central principle in all Mozambican Constitutions and a consistent directive in government policies and laws. To test the extent to which this principle has been materialized in the land sector, this paper provides a general overview of Mozambique's recent history and the role reserved for land in the formation of the state and in materialization of democratic governance. The paper concludes that more than any other factor, political party interference in public affairs has shaped the identity and performance of the Mozambican state, setting the stage for a complex interaction between the government, local people and private investors that has jeopardized the great potential of the national land policy and law to promote effective and sustainable participatory development processes.
\end{abstract}

Keywords: Land governance; participation; communities; investments; development.

São Paulo. Vol. 24, 2021

Debating Ideas: Decolonial Insurgences and Emancipatory Horizons

DOI: http://dx.doi.org/10.1590/1809-4422asoc20210163vu2021L5ID 


\section{Introduction}

O poder e as facilidades que rodeiam os governantes podem corromper facilmente o homem mais firme. Por isso, queremos que vivam modestamente e com o povo. Não façam da tarefa recebida um privilégio ou um meio de acumular bens ou distribuir favores.

Samora Machel, $1986^{1}$

Mozambique is located in Southern Africa's east coast, with the Indian ocean to the east coast and shared borders with Tanzania, Malawi, Zambia, Zimbabwe, Swaziland and South Africa and is a former Portuguese colony. As a result of its success in maintaining a climate of peace and political stability since the end of the first post-independence civil war in 1992, Mozambique has achieved impressive levels of economic performance and growth and has been regarded as a safe ground for both national and international investors (WORLD BANK, 2010; MACUANE et al., 2017). Since its independence from Portugal in 1975, a formal commitment to democracy and popular participation in the national development process has been a central principle in all Mozambican Constitutions and a consistent directive in government policies, strategies and laws. Indeed, FRELIMO (Frente de Libertação de Moçambique) has consistently upheld this principle within its discourse as a liberation movement (1962-1974), as leader of the post-independence single-party communist state (1975-1994), and as the party that has won multi-party elections under the democratic regime since 1994 and continues to govern the country until today.

To test the extent to which this principle has been materialized in practice, this paper provides a general overview of Mozambique's recent history as a nation and the role reserved for land in the formation of the state and in materialization of democratic governance. For this purpose, the paper analyses how the progressive content of the land policy and law approved in 1995 and 1997 respectively have been materialized in the prevailing political context in Mozambique. It uses as a reference the manner in which the government has framed the role of private investors and land-based investments and how this has impacted on its proclaimed mission to both protect citizens and communities land rights and promote participatory land governance and sustainable rural development. A discussion of challenges in the implementation process is included in the section that precedes the conclusion.

The main conclusion of the paper is that more than any other factor, political party interference in public affairs has shaped the identity and performance of the Mozambican

1 - Author's translation: "The power and privileges that surround rulers can easily corrupt the strongest man, so we want you to live modestly and with the people. Do not use your positions as privileges or as means of accumulating assets or distributing favours." (Samora Machel, president of the Republic of Mozambique from 1975 to 1986). 
state. This has set the stage for a complex interaction between the government, local people and private investors that has jeopardized the great potential of the national land policy and law to promote effective, just and sustainable participatory development processes.

This paper is an adaptation of the two first chapters of the doctoral thesis defended by the author in 2020, at the Utrecht University in the Netherlands with the title "Land-based Investments in Mozambique: Challenges in Community Rights Protection, Participation and Benefit Sharing". The thesis has substantially drawn on the author's experience as an environmental lawyer and practical work as a public interest advocate in land and natural resources issues in Mozambique over the last 17 years. As General Director of Centro Terra Viva (CTV)², from 2002 to 2015, and as Senior Legal Advisor from 2016 to date, the author followed different land-related processes both at the central and local levels in the whole country and led CTV legal support to communities affected by the projects described in this paper. The author promoted and attended policy debates and policy/law formulation processes, followed largescale land-based investment projects, as well as Community-Based Natural Resources Management (CBNRM) projects, which helped in getting insight into the challenges faced by the environmental sector in general, and by the land management and administration sector in particular.

\section{The Role of Land in the Formation and Consolidation of the Mozambican State and Mozambique Investment Strategy}

For the Mozambican government, promoting investments, especially foreign direct investments (FDIs), was seen as the best way to fast track development and secure funds to reconstruct the social and economic infrastructure network destroyed by the country's civil war, which lasted 16 years, from 1976 to 1992 (GOM, 2000, 2005, 2009, 2015).

Likewise, despite economic regime changes experienced by the country since independence (socialism from 1975 to 1990 and capitalism from 1990 onwards), in theory the Mozambican government maintained a consistent people-centred development policy (GOM, 1975, 1990, 2004). At least in theory, this policy gave prominence to the state's responsibility to protect citizens and local community rights (GOM, 1995). In this context, state's responsibility to protect citizens and local communities' land rights, particularly in the context of land-based investment promotion, was given particular attention in the 1995 National Land Policy (NLP) (GOM, 1995) through mandatory requirement for both the government and companies to consult with local communities to get their consent and to negotiate mutually beneficial situations when intending to use their land and other resources. The following policy objective can be found in the 1995 NLP:

To guarantee the rights of the Mozambican people to land and natural resources, as well as to promote investment and sustainable and profitable use of these resources. (GOM, 1995)

2- CTV is a multidisciplinary non-governmental organization dedicated to environmental research and advocacy, established in 2002 (www.ctv.org.mz /Centro Terra Viva - Estudos e Advocacia Ambiental). 
To materialize the NLP directive, a participatory process ensued in 1995 and 1996 (TANNER, 2002) which culminated with the approval of the 1997 Land Law still in force today. The land law review process is in itself considered emblematic due to the highly consultative approach adopted and the substantial involvement and leadership from both the government and civil society organizations, with support from the FAO (NEGRÃO, 2000). This process was described by Turner (2010), who at the time served as Senior Technical Advisor to the FAO in Mozambique:

The development of the Land Law itself was a major achievement, not only because it provided an innovative and workable solution to very complex problems, but also because it was developed through a participatory exercise that included civil society, academics, and all line ministries and sectors with an interest or role in land and resource management. It had, and still has, widespread support across the country, especially among those who promote local, communitybased development and who expect the state to respect and protect the basic rights of its citizens (p. 121).

Guidelines for national development processes, including for foreign investment, were also provided in several provisions of the Constitution of the Republic, as transcribed in Table I.

Table. I: Mozambique National Economic Organization

\section{Article 96: Economic Policy}

1. The State's economic policy is directed to the construction of the fundamental bases of development, improving people's living conditions, strengthening the sovereignty of the State and the consolidation of national unity, through the participation of citizens as well as the efficient use of human resources and materials.

2. Without prejudice to balanced development, the State guarantees the distribution of national wealth, recognizing and valuing the role of the producing areas.

\section{Article 98: Public Property and Public Domain}

1. Natural resources located in the soil and subsoil, in the territorial sea, in the continental shelf, in interior waters, and in the economic exclusive zone are the property of the state.

\section{Article 101: Economic Activity Coordination}

1. The State promotes, coordinates, and oversees economic activity, acting directly or indirectly to solve the fundamental problems of the people and to reduce social and regional inequalities.

2. State investment should play a leading role in promoting balanced development.

\section{Article 102: Natural resources}

The State promotes natural resource knowledge, mapping, and valuation and determines the conditions for their use and enjoyment to safeguard national interests. 


\section{Article 103: Agriculture}

1. In the Republic of Mozambique agriculture is the basis of national development.

2. The State shall guarantee and promote rural development for multi-sectoral growth to meet the needs of the people and the economic and social progress of the country.

Article 104: Industry

In the Republic of Mozambique, industry is the driving factor of the economy.

\section{Article 108: Foreign Investment}

1. The State guarantees foreign investment, which operates in the framework of its economic policy.

2. Foreign ventures are allowed throughout the national territory and in all economic sectors, except those that are reserved for exclusive State property or exploitation.

Source: the author, 2021

Until recently Mozambique was in fact also considered a success story of democracy and of rapid and stable economic development in Africa ${ }^{3}$ (WORLD BANK, 2010; USAID, 2011), where progressive land laws are in place and embrace good governance principles (MOYO, 2010; CABRAL; NORFOLK, 2016). Indeed, a combined review of constitutional provisions from different legal instruments undertaken for this research, particularly legislation on land and natural resource, would give the reader a vision of a national development process directed at eliminating poverty by improving the living conditions for all citizens, with citizen participation in the sustainable use of the country's natural resources. In this context, state ownership over land and all other natural resources was constitutionally adopted in the name and for the benefit of all Mozambican citizens (GOM, 1975, 1990, 2004). Furthermore, Mozambique has been considered an exemplary case of a country with a progressive policy and legal framework containing provisions for local communities to benefit from land-based investments. The 1997 Land Law has been described as one of the best in Africa (WILY, 2011; MCAUSLAN, 2013; TANNER, 2002; NORFOLK; TANNER, 2007; BICCHIERI, 2014; TANNER, 2017).

This positive assessment of the country's legal framework is generally due to provisions on: (1) community consultations aimed at protecting community rights and ensuring their political and economic inclusion; (2) community-private partnerships aimed at allowing rural land to be used by external actors while maintaining community rights and promoting mutual benefits; (3) legal and institutional pluralism aimed at integrating customary norms and traditional leaders in natural resource management and allowing community-based land and natural resource management, and; (4) sustainable public and private land-based investments that respect community rights and interests and promote sustainable rural development.

Despite this policy and legal framework, however, land-based investment projects, both national and foreign, and both public and private, have increasingly been involved

3. The last 10 years have witnessed worrying signs of a decrease in democratic spaces and processes, exacerbated by a financial scandal that has seriously damaged the country's reputation and severely undermined its economic progress. 
in conflicts and tensions with local citizens and communities in both rural and urban areas (MOSCA; SELEMANE, 2012; CTV, 2018; MOSCA et al., 2014; OMR, 2015; CABRAL; NORFOLK, 2016). In both public and private investments, investors have generally failed to consult with local communities and to respect their land rights (CABRAL; NORFOLK, 2016). They have also been found to trigger unjustified involuntary displacements and resettlements, failing to equitably share any tangible economic benefits with local populations and to provide visible contributions to local development (IESE, $2012,2015)$. For these reasons, land-based investments in this country are seen more as land-grabbing manoeuvres than as development opportunities (OMR, 2014; IESE, 2012, 2013, 2015; ASCUT, 2017). Mozambique is thus often mentioned in land grabbing debates and placed at the top of the list of countries where foreign companies and national elites are acquiring large extensions of land in rural areas at the jeopardy of national citizens and local communities (HANLON, 2010; MILGROOM, 2013; ILC 2010; COTULA et al., 2009; NHANTUMBO; SALOMÃO, 2010).

Analysts of Mozambique's land sector, from the academy, civil society, and even from the government, agree with these claims and assert that in spite of the favourable legal framework and people-centred policies, the rights of local communities to access, occupy, and use land and other natural resources have been increasingly threatened, with communities marginalized from relevant land-related decision-making processes and also left behind in economic opportunities and benefits sharing (NEGRÃO, 2002; TANNER, 2010; TANNER; BICCHERI, 2014; TRINDADE; SALOMÃO, 2016; CABRAL; NORFOLK, 2016; CIP, 2016).

While recognizing existing imperfections within the law and that the law might have to assume a share of the blame (WILLY, 2011), these analysts generally converge on the conclusion that Mozambique's land governance is being hampered by extra-legal factors, such as political and economic elites interference, corruption and generalized legal illiteracy among local communities in both rural and urban areas. Arguably, the current content of the law, including its alleged imperfections, might even be a reflection of tensions and compromises imposed by such factors, hence the comment that this is the law that was possible to approve under the country's social, political, and economic circumstances of the time. Claiming that bad natural resources governance stems from how a 'political settlement' has been organized and rent mobilization controlled by the ruling party, Macuane et al. (2017) also argued that:

Despite the increasing investments in natural resources, the country still experiences what has been termed as 'growth without change', with resettlement problems, low levels of contribution to GDP, and poor linkages between megaprojects and other sectors of the economy. (...) A key foundation of the political settlement in postindependence Mozambique has been the ideology of 'national unity' fostered by the ruling party Frelimo, which informs patronage and clientelism. (p. 5-6). 


\section{Mozambique Investment Strategy}

Land and other natural resources are Mozambique's biggest socio-cultural and economic asset, both for national citizens and families as well as for the state. For the state, investments on land have been seen and treated as catalysers of national socioeconomic development, with the potential to provide important contributions to the country's fight against poverty, particularly rural poverty.

Following the constitutional directive to make agriculture the main economic sector, the initial focus of the state after independence was to organize and boost agricultural production through both large state farms that were inherited from colonial companies, and through small farmers organized in farmers' associations. This approach was soon abandoned as a result of political changes that took place in the 80 s and the resulting shift from socialism to capitalism and free market. The investment promotion strategy that ensued did not provide clarity in terms of priority sectors, or at least in terms of linkages between other economic sectors and agriculture. As a result, investments were attracted to all economic sectors and not necessarily to the agriculture sector and much less to the small family farming sector (MOSCA; SELEMANE, 2012). An assessment undertaken by IESE in 2013 (IESE, 2013) shows the sectoral tendency of investments approved in the period from 1990 to 2011 as detailed in Table II.

Table II. Total Investments approved between 1990 and 2011

\begin{tabular}{|l|l|}
\hline Sector & $\%$ of Private Investments Approved \\
\hline Mineral Resources and Energy & $29 \%$ \\
\hline Agriculture and Agroindustry & $25 \%$ \\
\hline Industry & $18 \%$ \\
\hline Tourism and Hotels & $9 \%$ \\
\hline Transports and Communication & $8 \%$ \\
\hline Construction & $4 \%$ \\
\hline Services & $2 \%$ \\
\hline Banks, Insurance and Leasing & $2 \%$ \\
\hline Other & $2 \%$ \\
\hline Aquaculture and Fisheries & $1 \%$ \\
\hline
\end{tabular}

Source: Adapted from Massingue and Muianga (2013).

While investment attraction directed to the agribusiness sector represented 25\% in this period (IESE, 2013), this comprised mostly large forest plantations and game reserves which occupy vast amounts of land (MASSINGUE; MUIANGA, 2013). Furthermore, 
investments in agriculture were not directed to supporting small farming food production but rather to large scale agribusinesses for export monocultures such as cotton, tobacco, sugar, cashews, and timber (MOSCA; SELEMANE, 2012; MASSINGUE; MUIANGA, 2013), and for biofuels-related crops such as sugar cane and jathropa (NHANTUMBO; SALOMÃO, 2010). In the latter case, campaign efforts were directed at mobilizing small rural farmers to cede their lands to investors (mostly foreign) interested in planting sugarcane and jathropa, or to convince small farmers to use their lands to plant crops for biofuels. The biofuels hype resulted in a major failure that fell short of producing needed results (NHANTUMBO; SALOMÃO, 2010), but the land withdrawn from rural communities was never returned to them and their economic expectations were crushed in the process. Between 1990 and 2011, the majority of investments were directed to the mining and energy sector, representing 29\% of the total investments approved (MASSINGUE; MUIANGA, 2013). This sector steadily occupied the first position throughout the last decade, during which the shift to and focus on extractive industries (mining and hydrocarbons) and to public infrastructure projects was substantial (CASTEL-BRANCO, 2015).

The tendency of land-based investments in the country, summarized in 2015 by Muianga (2015), was based on data from the Land Matrix. While, like other researchers (COTULA et al., 2009), Muianga (2015) also raises reservations about the reliability of the data, he asserts that this data nevertheless provides a good indication of the pressure on rural lands imposed by land-based investors, particularly in what respects land scale, sectors, and actors. Muianga's data on some of these aspects is shown in the table below.

Table III. Main investors by country of origin, land size and sector of investment, 2004-2013

\begin{tabular}{|l|l|l|l|}
\hline & Country of Origin & Sectors & Land size \\
\hline 1 & Portugal & $\begin{array}{l}\text { Forest plantations, food production, bio- } \\
\text { fuels }\end{array}$ & $384.721 \mathrm{ha}$ \\
\hline 2 & South Africa & Tourism, food production, biofuels & $222.920 \mathrm{ha}$ \\
\hline 3 & U.S. America & Forestry and fibre & $168.170 \mathrm{ha}$ \\
\hline 4 & Zimbabwe & Food production and biofuels & $150.00 \mathrm{ha}$ \\
\hline 5 & Norway & $\begin{array}{l}\text { Nature conservation, carbon sequestra- } \\
\text { tion. Timber and fibre }\end{array}$ & $130.800 \mathrm{ha}$ \\
\hline 6 & U. Kingdom & Food production, biofuels, and livestock & $63.029 \mathrm{ha}$ \\
\hline
\end{tabular}

Source: MUIANGA, 2015.

In the first three decades after the country's independence, national private investors were practically non-existent. This sector was essentially taken up by political and economic elites that emerged in the transition phase from socialism to capitalism and who used their influence and links with the state merely to secure land and other resources thus positioning themselves strategically for the upcoming economic liberalization (CASTEL-BRANCO, 2013).

Therefore, while there is a tendency to focus attention on foreign investors, includ- 
ing in what relates to land conflicts with local communities, as pointed out by Muianga (2015), the role of national elites and investors, including the government, in attracting and facilitating large-scale land acquisitions should not be underestimated. In this context, a report issued by the World Bank (WORLD BANK, 2010) highlights the role of domestic actors, indicating that $53 \%$ of the 2.670 .000 ha transacted between 2004 and 2009 in Mozambique were allocated to national investors. According to Muianga (2015), in many of the projects listed in Table III above, Mozambican investors are associated with investors through joint ventures.

\section{From Theory to Practice: Investment Projects and the Challenge of Implementing the Progressive Land Policy and Law}

The projects described below have been selected to allow discussion of various aspects of the 'good land governance' question identified in the introduction to this paper. First, except for community projects, all projects, including public projects, involved investor requests for land use rights which overlapped and conflicted with pre-existing community land use rights. These projects also involve on-going or planned community land rights expropriation with economic and/or physical involuntary resettlements.

Second, to ensure diversity and better representation of projects for the whole country, and to assess whether similar problems occurred both across sectors and regions, the cases were selected from different sectors and are located in different regions of the country. The geographical diversity was also used to assess how customary norms and cultural specificities of each region have influenced the format and outcomes of community engagement processes organized by the government and investors, including community consultations and other mechanisms of community participation. It was also used to assess whether community involvement strategies and concerns differ according to their geographical location and cultural specificities, particularly involvement of women. The projects were selected from different economic sectors, with the objective of understanding if there are sector-based differences and specificities and if the relative economic and financial weight of each sector and investor, such as the oil and gas sector, make a difference in both procedural and distributive terms.

Third, both private and public investments, as well as community investment projects are analysed, to assess if the category of actors leading the projects translates into differences in how participation modalities are used, on how community consultations, public meetings, and other participatory procedures are conducted, and the manner in which affected citizens are economically included and share benefits. For the purpose of this paper, public projects are those led by the state and financed by public funds, even if from a foreign source; private projects refer to projects led by private companies holding a majority of shares in the ventures and also covering most of the financial costs, including projects that involve the state as a minority shareholder; community projects are projects designed by, with, or for local communities, even when technical and financial resources are provided by external partners such as the government, private companies, or non-governmental organizations. The circles shown in the map below indicate the 
project's geographical location.

Figure I - Geographical Location of Investment Projects Analysed (in circles)

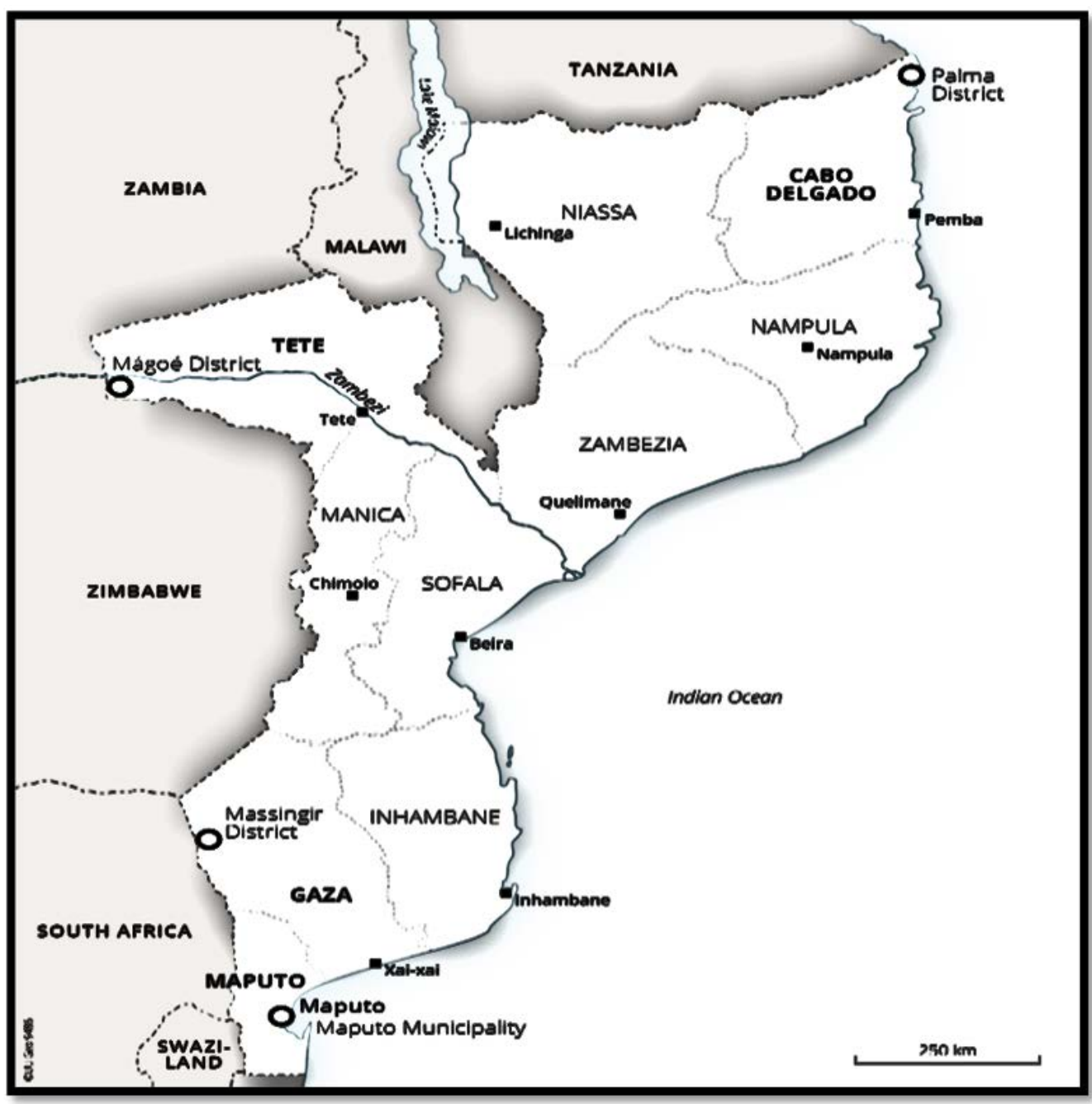

Source: the author, 2021

\section{The Limpopo National Park in Massingir District, Gaza Province}

The District of Massingir richness in wildlife and its borders with South Africa led to the establishment of the Limpopo National Transfrontier Park (LNTP) in 2001, linking the Kruger National Park and the Zimbabwean Gonarezhou National Park with 
what was then an official hunting reserve (Coutada 16) ${ }^{4}$. On the Mozambican side, the original hunting reserve was extended to form the Limpopo National Park (LNP) over an area of 1.123.316ha, expanding through three districts, namely Massingir, Mabalane and Chicualacuala, in Gaza Province. In Massingir the LNP covers 40\% of the District area, in an area that housed about 27.000 people. The creation of the LNP imposed the forced displacement of the original land occupants. This involuntary resettlement process has faced numerous social, technical and financial hurdles since the decision was made in 2003 and has still not been finalized. Out of the eight communities targeted for resettlement only three have so far been moved in processes mired by human-wildlife conflicts and community protests. No expropriation process was ever conducted.

\section{The Cubo Community Game Park Project in Massingir District, Gaza Province}

The creation of the Limpopo National Park (LNP) was promoted as an opportunity for communities to benefit from the revenues expected to be generated by the park and also to be included in economic endeavours through promotion of community-based investment projects. As indicated in its Management Plan, these include community ecotourism projects. The LNP buffer zone was classified as adequate for both private and community ecotourism projects (Ibid.) and since its establishment about five private ecotourism projects and two community ecotourism projects were approved for implementation in its buffer zone. One of the community projects developed in the LNP buffer zone was set up by the Cubo Community. This project comprised the establishment of a game reserve in an area of $10.000 \mathrm{ha}$, the 'Cubo Game Park', as well as the construction of a community lodge. To secure assistance in fundraising and in project management, the Cubo community signed partnership agreements with both national and foreign private investors (the Mozambican Ngeneya Project and the South African Twin Cities, respectively). Due to investors' forceful insistence in acquiring more community land, the relationship between the Cubo community and its partners was marred by conflicts which ended only after a long and turbulent mediation process that lasted from 2014 to 2018, undertaken by the national NGO Centro Terra Viva (CTV) at the parties' request.

\section{The Mágoè National Park in Mágoé District, Tete Province}

In 2013, thirteen years after the creation of the Limpopo National Park (LNP), the Mozambican government created the Mágoè National Park (MNP) in the central province of Tete, Mágoè District. Similar to the LNP, the Mágoè National Park was established as part of a transboundary nature conservation area (ZIMOZA), jointly with Zimbabwe and Zambia, with which it shares borders. The largest area of the PNM is located in the Mágoè District, and the 5 localities from Mágoè district covered by the extension of the Park have a total of 30,452 inhabitants. While no decision has been taken to resettle

4- The Park was created on November 27, 2001, altering the category and dimensions of a former hunting concession (Coutada 19) through a partnership between the government of Mozambique and the Peace Parks. 
the communities residing within the park area, neither community consultations nor the required expropriation process were ever conducted.

\section{The Tchuma Tchato Community Project in Mágoè District, Tete Province}

The Tchuma Tchato Community Program (TTP) was the first community-based natural resources management (CBNRM) project established in Mozambique in 1995 (GOM, 1995). This project was promoted by the government, in the same area that has now been occupied by the Mágoè National Park. This project started in an area of approximately 200.000 hectares, and its emergence was fundamentally due to the need to resolve conflicts between local communities and private safari operators. As local communities claimed that they were not benefiting from such operations, the project aimed at reducing such conflicts through promotion of natural resources conservation with the involvement of local communities, also ensuring that benefits derived from private exploitation of natural resources would be accrued by local communities in a substantial manner. From 1995 to 2010, the project was technically supported by the government and financially supported by the Ford Foundation and a revenue distribution scheme among local communities, district, provincial and central governments was approved. Due to disagreements about equity in revenue sharing between local communities, on the one side, and the provincial and central governments on the other side, the Tchuma Tchato project was unilaterally cancelled by the central government through creation of the Mágoè National Park. The argument advanced by the government was that communities were receiving large amounts of funds which they did not know how to manage and which were substantially higher than those received by the government.

\section{TOTAL (ex-Anadarko) Liquefied Natural Gas Project in Palma District, Cabo Delgado Province}

In 2010, the American private company Anadarko confirmed the existence of substantial natural gas reserves in the basin of the Rovuma River, located in the Northern part of Mozambique. The Afungi Peninsula, in Palma District, was selected to house the infrastructure needed to process and export liquefied natural gas, allegedly due to its low population density and environmental risks. However, the Afungi Peninsula is home to 12 local communities. Anardarko's project directly impacts on land occupied by $4 \mathrm{com}$ munities, namely Quitupo, Maganja, Senga, and Patacua.

The largest of these communities, Quitupo, with about 2750 inhabitants in 2012, has been targeted for both physical and economic resettlements. Without consulting with affected communities, without delimitating the community area and without conducting the legally mandatory land rights expropriation process, in 2012 the government granted land use rights to Anadarko's project over 7000ha of the Quitupo land, through a land use rights title (DUAT) issued in the name of a subsidiary of the National Hydrocarbons Company (ENH), the Rovuma Basin LNG Land (RBLL). After this, Anadarko signed a land leasing agreement with RBLL thus acquiring exclusive access and use rights over 
the afore mentioned land. Quitupo community is expected to be moved to a resettlement village being built in a land (Quitunda) belonging to the neighbouring community of Senga. The Afungi Resettlement Plan (ARP) was approved in December 2016 and the resettlement village construction was initiated in 2018. The first families were expected to be moved in early 2019. Due to the illegality of the DUAT process, at CTV's request, in 2016 the Mozambican Bar Association filed a court case against the Mozambican state in the name of the Afungi communities, challenging the legality of the project's DUAT. In 2019, the administrative court decided to uphold the illegality alleging that the communities were happy with the compensation money paid by the company.

\section{The Maputo-KaTembe Bridge and Highway Project in Maputo City}

In 2010, the Government of Mozambique (GoM) approved an infrastructure project, funded by the Government of China, and comprising the construction of over $200 \mathrm{~km}$ of a ring road around the national capital city of Maputo, the Maputo-KaTembe bridge linking the main city (Maputo) with the town of KaTembe across Maputo bay, and a road starting from the southern end of the bridge through to South Africa via the coastal district of Matutuine, where the Ponta D'Ouro Marine Reserve is located. Both the bridge and the highway have imposed the involuntary resettlement of numerous families that resided in formal and informal neighbourhoods in Maputo city. The Maputo-KaTembe bridge, in particular, required the resettlement of approximately 1200 families from three peripheric neighbourhoods, namely Malanga, Luis Cabral, and Gwachene. The Bridge was inaugurated in December 2018. While some families are happy with the new conditions they have in the relocation sites, other families complain about the manner in which compensation packages were designed and their removal was conducted, complaining also about lack of social infrastructure and livelihoods opportunities in the new sites.

\section{Discussion}

The previous sections show that Mozambique's legitimate interest in attracting investments has materialized in a manner that did not honour the reputation gained by its policy and legal framework, especially in what concerns the responsibility of the government to protect the rights of rural and peri-urban communities. The reality of ill-prepared rural citizens and communities is exacerbated by poor government interest and rigor in protecting community rights, by poor land zoning and territorial planning, particularly at the district level, as until now no single PDUTs (district land use plan) has been published in the national gazette (and thus are legally non-existent). Lack of private investors commitment to good governance through respect of both procedural norms and equitable benefits distribution should also be added to these factors. As a result, despite Mozambique's progressive legal framework, the demand for large areas of land for economic projects, but also for expansion or creation of urban areas triggered by such projects, has created space for conflicts between local communities and the government; conflicts between local communities and investors; and conflicts between local communi- 
ties and the government and investors together (NHANTUMBO; SALOMÃO, 2010; MOSCA; SELEMANE, 2012; HRW, 2013). Inter and intra-sectoral conflicts within and among government institutions are also notorious (NHANTUMBO; SALOMÃO, 2010).

Furthermore, the increasing occurrence of economic and physical involuntary resettlements of local communities in the last few decades, to give room to public and private investments, has given rise to social protests, exacerbating tensions and conflicts amongst all those actors (HRW, 2013; ICM, 2016; MOSCA; SELEMANE, 2012; UNAC, 2014; OMR, 2015). In fact, government investment promotion in Mozambique has placed this country on the route of the global rush, with government agents often taking the lead in this process. In spite of the stated justification for maintaining the principle of state property over land — ensuring that the rights of Mozambicans are protected—investment campaigns and the allocation of lands to investors have not always been conducted in a manner that prioritizes protection of local land rights or pursuit of public interest defined in terms of what is best for 'the public': the people of Mozambique.

LANDESA underlined the points above in a 2011 study when they concluded that "most of these farmland acquisitions are occurring in low-income and middleincome countries, often in settings where land property rights are weak, unclear, and poorly governed — creating enormous risks for poor people, investors, and governments" (LANDESA, 2011, p. 1). Referring to Mozambique and Madagascar, LANDESA (2011) also claimed that these countries had received requests from investors for more than half of their total cultivable land area.

Thus, while such requests might not have all been positively responded to, the rush for lands in Mozambique has created a kind of 'wild west' situation where government agents and those close to them can manipulate the principle of state ownership in their favour, while weak land administration agencies fail to effectively implement even the safeguards that do exist in the land legislation (MOSCA; SELEMANE, 2012). Consequently, Mozambique is also known for being one of the top targets of global land grabbing (GRAIN, 2008; ILC, 2010; WORLD BANK, 2010; LANDESA, 2011; UNAC, 2014).

In this context, a recent evaluation of the legal framework for land-based investments in Mozambique (CABRAL; NORFOLK, 2016) concluded that:

The ability to protect the legally acquired land rights of rural communities has been further challenged by the surge in demand for land that has accompanied Mozambique's economic development and, until recently, the large inflows of FDI attracted to the country by natural resource endowments, price incentives and the development of special economic zones and growth corridors. In a context of a fragile governance framework, this has resulted in unlawful land occupation and widespread conflict with the local population. (p. 45)

Another recent assessment of Mozambique land governance (TRINDADE; SALOMÃO, 2016) indicates that government agents have deliberately chosen to subvert the principle of state ownership over land and to by-pass the legal procedures aimed at 
benefiting national citizens and serving national interests. This assessment shows that the principle of state ownership, combined with the argument about the need to combat poverty, has instead been used to justify allocating land use rights to investors over community lands, in both rural and urban areas, ignoring mandatory procedures imposed not only by the Constitution but also by the land and territorial planning legislation. In the context of land-based investments, this assessment indicated that both central and district governments are particularly failing to ensure observance of the following legally imposed procedures in the legally prescribed order, as follows:

1. Previous delimitation of community lands over which there is a public or private economic investments interest;

2. Formal declaration of public interest prior to any land allocation procedure;

3. Consultation and negotiation with local communities occupying the lands envisaged for public and private projects;

4. Prior negotiation and payment of fair compensation to affected citizens and communities before extinguishing pre-existing land use rights;

5. Formal declaration of extinction of individual and collective pre-existing land use rights;

6. Territorial zoning and categorization of the land envisaged by the projects, and issuance of new DUATs or special licenses, depending on the land category in question;

This report (TRINDADE; SALOMÃO, 2016) highlights the importance of identification, declaration, and demarcation of public domain areas, in consultation with local communities and with respect to citizens' rights, as also imposed by the Constitution.

An updated review on the impact of Mozambique's investment strategy particularly on citizen's rights was published by Wise (2016), revealing that the Mozambican government remains committed to giving away good land to foreign investors despite persistent resistance from affected communities which, he claims, might have led to the considerable level of failure of such projects. Based on data from the Land Matrix, Wise (2016) states:

In 2012, Mozambique was the second most important target in the world, with nearly 8 million hectares in reported agricultural deals. Now, the Land Matrix lists only 500,000 hectares in 65 concluded agricultural deals. Of the current projects, nine, on nearly 100,000 hectares, are listed as "abandoned," mostly biofuel projects. Data is scarcer on the area actually under production, but Land Matrix could confirm only 21,000 hectares in production. (...) Mining concessions continue to displace or threaten thousands of Mozambicans as the mineral boom continues. (para. 16)

Indeed, the mineral and hydrocarbons boom continues even today in Mozam- 
bique, with a continued display of the same social problems and sectoral discoordination mentioned in this paper.

\section{Conclusion}

In principle, the policy and legal framework discussed above, and the various constitutional principles on which it is grounded provide a good platform for promoting the kind of democratic and participatory development model that the Mozambican State has espoused from its earliest moments. It also provides clear mechanisms that should ensure an equitable process of new investment, which safeguards the interests of local people and generates real benefits that should enhance their livelihoods and quality of life. However, as the projects selected help to explain, Mozambique has become a byword internationally for land grabbing and for setting aside established legal norms and principles. The role of the state and what and who the state is are key here, and provide possible explanations on the reasons why the government (in its role as state representative) has failed to do its share of the task.

Both the constitutional set-up and the philosophical underpinnings of the FRELIMO government, emphasize the notion that land and natural resources must remain the property of the state in order to ensure that the rights of citizens to access and use land are protected, and that land and natural resources are to be used for the 'public interest' (i.e. for national development). Yet, the discussion above shows how the rapid transition from a socialist-inspired approach to 'democratic governance' and a free-market system while still encumbered with the institutional architecture and ideology of the earlier regime, has created tensions between the people-centred agenda that is implicit in the progressive policy and legal framework for land developed in the 1990s and the neoliberal/capitalist agenda that is now strongly embraced by FRELIMO and national elites.

\section{References}

ASCUT. Perfil de Terras em Moçambique - Relatório Final. Maputo, 2017.

CABRAL, L.; NORFOLK, S. Inclusive Land Governance in Mozambique: Good Law, Bad Politics? Institute of Development Studies (IDS) Working Paper 478, 2016.

CASTEL-BRANCO, C. Reflectindo Sobre a Acumulação, Porosidade e Industrialização em Contexto de Economia Extractiva. In. Desafios para Moçambique 2013. Maputo: IESE, 2013.

CASTEL-BRANCO, C. "Capitalizando" O Capitalismo Doméstico: Porosidade e Acumulação Primitiva de Capital em Moçambique. In. Desafios para Moçambique 2015. Maputo: IESE, 2015.

CIP. Num Contexto de Crise das Commodities - Desafios de um País Potencialmente Rico 
em Recursos Minerais: Estabelecendo as Bases para Evitar a "Maldição dos Recursos" em Moçambique no Novo "Superciclo" dos Preços das Matérias-Primas, 2016. Retrieved from www.cip. org.mz/publicações.

COTUlA, L.; VERMEULEN, S.; LEONARD, R.; KEELEY, J. Land Grab or Development Opportunity? Agricultural Investment and International Land Deals in Africa. London/Rome: IIED/FAO/IFAD, 2009.

CTV. Relatório de Monitoria da Governação de Terras. CTV: Maputo, 2018.

GOM. Resolução da Assembleia Popular - Aprova a Constituição da República Popular de Moçambique, 1975.

GOM. Lei N. 6/79, de 3 de Julho - Aprova da Lei de Terras, 1979.

GOM. Resolução da Assembleia da República - Aprova a Constituição da República de Moçambique, 1990.

GOM. Resolução N.o 10/95, de 28 de Fevereiro - Aprova a Política Nacional de Terras, 1995.

GOM. Resolução N. 8/97, de 1 de Abril - Aprova a Política Nacional de Florestas e Estratégia de Implementação, 1997.

GOM. Lei N. $19 / 97$, de 1 de Outubro - Aprova a Nova Lei de Terras, 1997.

GRAIN. Seized! The 2008 Land Grab for Food and Financial Security. Grain Briefing, 2008. Retrieved from www.grain.org/system/old/briefings_files/landgrab-200

HANLON, J. Mozambique's Elite: Finding its Way In a Globalised World and Returning to Old Development Models, 2010. Retrieved from: www.lse.org/Internationaldevelopment/research/ crisisStates

HUMAN RIGHTS WATCH. What is a House Without Food? Mozambique's Coal Mining Boom and Resettlements, 2013.

IESE. Desafios Para Moçambique 2012. Maputo: IESE, 2012.

IESE. Desafios Para Moçambique 2013. Maputo: IESE, 2013.

IESE. Desafios Para Moçambique 2015. Maputo: IESE, 2015.

ILC. Annual Report, 2010. Retrieved from www.ilc.org

LANDESA. Issue Brief: The Global Land Rush, 2011. Retrieved from www.landesa.org

MCAUSLAN, P. Land Law Reform in Eastern Africa: Traditional or Transformative? A Critical Review of 50 Years of Land Law Reform in Eastern Africa 1961-2011. Abingdon, UK: Routledge, 2013. 
MACUANE, J.; BUUR, L.; MONJANE, C. Power, Conflict and Natural Resources: The Mozambican Crisis Revisited. African Affairs, v. 117, n. 468, p. 415-438, 2018.

MASSINGUE, N.; MUIANGA, C. Tendências e Padrões de Investimento Privado em Moçambique: Questões para Análise. In. Desafios Para Moçambique 2013. Maputo: IESE, 2013. p. $125-147$.

MILGROOM, J. Policy Processes of Land Grab: Enactment, Context and Misalignment in Massingir, Moçambique. LDPI Working Paper 34, 2013.

MOSCA, J; SELEMANE, T. Mega-Projectos no Meio Rural, Desenvolvimento do Território e Pobreza: O Caso de Tete. In. Desafios Para Moçambique 2012. Maputo: IESE, 2012.

MOSCA, J.; ABBAS, M.; BRUNA, N. Governação, 2004-2014: Poder, Estado, Economia e Sociedade. Maputo: Alcance Editores, 2014.

MOYO, S. Land Reform, Small Scale Farming and Poverty Eradication: Lessons from Africa. AISA Policy Brief 21, 2010.

MUIANGA, C. Dinâmicas Actuais de Acquisição de Terra para Investimento em Moçambique: Tendências, Escala, Factores, Actores, e Questões para Análise. In. Desafios Para Moçambique 2015. Maputo: IESE, 2015.

NEGRÃO. A Indispensável Terra Africana para o Aumento da Riqueza dos Pobres, 2000. Retrieved from https://www.ces.uc.pt/publicacoes/oficina/ficheiros/179.pdf

NHANTUMBO, I.; SALOMÃO, A. Biofuels, Land Access and Rural Livelihoods in Mozambique. London, IIED Working Papers, 2010.

NORFOLK, S.; TANNER, C. Improving Tenure Security for the Rural Poor: MozambiqueCountry Case Study. Legal Empowerment of the Poor (LEP) Working Paper 5, 2007.

OMR. Legislação Sobre Recursos Naturais em Moçambique. Convergências e Conflitos na Relação com a Terra. Observador Rural, Documento de Trabalho 28, 2015.

TANNER, C. Law-Making in an African Context: The 1997 Mozambican Land Law. FAO Legal Paper Online 26, 2002. Retrieved from http://www.sarpn.org.za/CountryPovertyPapers/Mozambique/Legal/tanner.php

TANNER, C. Land Rights and Enclosures: Implementing the Mozambican Land Law in Practice. In Struggle Over Land in Africa. Pretoria: HSRC and University of Pretoria, 2010.

TANNER, C.; BICCHIERI, M. When the Law is not Enough: Paralegals and Natural Resources Governance in Mozambique. Maputo: FAO, 2014.

TANNER, C Land Tenure Assessment for The ER-PD. Etc Terra, 2017.

TRINDADE, J.; SALOMÃO, A. Arranjos e Políticas Institucionais. In. TRINDADE, J. SA- 
LOMÃO, A. (Eds.). Avaliação da Governação de Terras em Moçambique. LGAF-Moçambique/2015-2016. Maputo: MITADER, 2016.

UNAC. Declaração Anual Final, 2014.

USAID. USAID Country Profile: Mozambique-Property Rights and Resource Governance, 2011.

WILY, L. A. The Law is to Blame: The Vulnerable Status of Common Property Rights in Sub-Saharan Africa. Development and Change, v. 42, v. 3, p. 733-757, 2011.

WISE, T. Land Grab Update: Mozambique, Africa Still in the Crosshairs. GDAE Globalization Commentaries, 2016.

WORLD BANK. Rising Global Interest in Farmland: Can it Yield Sustainable and Equitable Benefits? Washington Dc: World Bank, 2010. 


\section{Alda Salomão}

\alda.salomao@tindzila.com

ORCiD: https://orcid.org/0000-0001-8373-9799
Submitted on: 02/09/2021

Accepted on: 06/09/2021 2021;24e:0163

How to cite: SALOMÃO, Alda. Participatory Land Governance in Mozambique: Brief Review of the Legal Framework and the Implementation Challenge. Ambiente $\mathbb{\&}$ Sociedade. São Paulo, v. 24, p. 1-22, 2021. 


\title{
Governação Participativa de Terras em Moçambique: Breve Revisão do Quadro Legal e Desafios de Implementação
}

\author{
Alda Salomão
}

São Paulo. Vol. 24, 2021

Ideias em Debate: Insurgências Decoloniais e Horizontes Emancipatórios

\begin{abstract}
Resumo: O compromisso com a democracia e participação popular no desenvolvimento nacional tem sido um princípio central em todas as Constituições moçambicanas e uma diretriz consistente nas políticas e leis governamentais. Para verificar como este princípio foi materializado no setor da governação da terra, este artigo fornece uma visão geral da história recente de Moçambique e do papel reservado à terra na formação do Estado e materialização da governação democrática. $\mathrm{O}$ artigo conclui que mais do que qualquer outro fator, a interferência político-partidária nos assuntos públicos moldou a identidade e o desempenho do Estado moçambicano, criando o cenário para uma interação complexa entre o governo, a população local e os investidores privados, pondo em risco o grande potencial da política e da lei de terras nacionais para promover processos de desenvolvimento participativo eficazes e sustentáveis.
\end{abstract}

Palavras-chave: Governação da terra; participação; comunidades; investimentos; desenvolvimento

Como citar: SALOMÃO, A. Governação Participativa de Terras em Moçambique: Breve Revisão do Quadro Legal e Desafios de Implementação. Ambiente \& Sociedade. São Paulo, v. 24, p. 1-20, 2021.

DOI: http://dx.doi.org/10.1590/1809-4422asoc20210163vu2021L5ID 


\title{
Gobernanza Participativa de Tierras en Mozambique: Breve Revisión del Marco Legal y Desafíos de Implementación
}

\author{
Alda Salomão
}

São Paulo. Vol. 24, 2021

Ideas en Debate: Insurgencias Decoloniales y Horizontes Emancipatórios
Resumen: El compromiso con la democracia y la participación popular en el desarrollo nacional ha sido un principio central en todas las constituciones mozambiqueñas y una directriz constante en las políticas y leyes gubernamentales. Para comprobar cómo se ha materializado este principio en el sector de la tierra, este documento ofrece una visión general de la historia reciente de Mozambique y del papel reservado a la tierra en la formación del Estado y materialización de la gobernanza democrática. El artículo concluye que, más que cualquier otro factor, la injerencia de los partidos políticos en los asuntos públicos ha configurado la identidad y la actuación del Estado mozambiqueño, sentando las bases para una compleja interacción entre el gobierno, la población local y los inversores privados que ha puesto en peligro el gran potencial de la política y la legislación nacional sobre la tierra para promover procesos de desarrollo participativos eficaces y sostenibles.

Palabras-clave: Gobernanza de la tierra; participación; comunidades; inversiones, desarrollo

Como citar: SALOMÃO, A. Gobernanza Participativa de Tierras en Mozambique: Breve Revisión del Marco Legal y Desafíos de Implementación. Ambiente $\&$ Sociedade. São Paulo, v. 24, p. 1-20, 2021.

DOI: http://dx.doi.org/10.1590/1809-4422asoc20210163vu2021L5ID 